\title{
Declining Wages Increase Selfish Redistribution in an Environment with Fixed Income Inequality
}

Citation for published version (APA):

Zaunbrecher, H., \& Gagnon, N. (2020). Declining Wages Increase Selfish Redistribution in an

Environment with Fixed Income Inequality. Maastricht University, Graduate School of Business and Economics. GSBE Research Memoranda No. 023 https://doi.org/10.26481/umagsb.2020023

Document status and date:

Published: 27/08/2020

DOI:

10.26481/umagsb.2020023

Document Version:

Publisher's PDF, also known as Version of record

\section{Please check the document version of this publication:}

- A submitted manuscript is the version of the article upon submission and before peer-review. There can be important differences between the submitted version and the official published version of record.

People interested in the research are advised to contact the author for the final version of the publication, or visit the DOI to the publisher's website.

- The final author version and the galley proof are versions of the publication after peer review.

- The final published version features the final layout of the paper including the volume, issue and page numbers.

Link to publication

\footnotetext{
General rights rights.

- You may freely distribute the URL identifying the publication in the public portal. please follow below link for the End User Agreement:

www.umlib.nl/taverne-license

Take down policy

If you believe that this document breaches copyright please contact us at:

repository@maastrichtuniversity.nl

providing details and we will investigate your claim.
}

Copyright and moral rights for the publications made accessible in the public portal are retained by the authors and/or other copyright owners and it is a condition of accessing publications that users recognise and abide by the legal requirements associated with these

- Users may download and print one copy of any publication from the public portal for the purpose of private study or research.

- You may not further distribute the material or use it for any profit-making activity or commercial gain

If the publication is distributed under the terms of Article $25 \mathrm{fa}$ of the Dutch Copyright Act, indicated by the "Taverne" license above, 
Henrik W. Zaunbrecher,

Nickolas Gagnon

Declining Wages Increase Selfish Redistribution in an Environment with Fixed Income Inequality

$\mathrm{RM} / 20 / 023$

ISSN: $2666-8807$

\section{GSBE}

Maastricht University School of Business and Economics

Graduate School of Business and Economics

P.O Box 616

NL-6200 MD Maastricht

The Netherlands 


\title{
Declining Wages Increase Selfish Redistribution in an Environment with Fixed Income Inequality
}

\author{
Henrik W. Zaunbrecher Nickolas Gagnon*
}

August 25, 2020

\begin{abstract}
We use a highly-controlled laboratory experiment to study the causal impact of income decreases on redistribution decisions, in an environment where the income inequality that may be created with wage changes is kept fixed. First, we investigate the role of a decreasing wage compared to one's past wage (intra-personal decrease). Second, we investigate the role of a wage that decreases relative to the wage of another person (inter-personal decrease). If intra-personal or inter-personal decreases create dissatisfaction for an individual, that person may support redistribution policies that compensate him or her for the situation or rectify it. Overall, we find evidence that individuals indeed behave more selfishly when they experience decreasing wages. While many studies examine the effect of income inequality on redistribution decisions, this is the first to isolate the effect of income changes.
\end{abstract}

Keywords: Income Inequality; Income Change; Social Preferences; Social Comparison; Income Redistribution

JEL Classification: C91, D31, D63

\footnotetext{
*Acknowledgements: Henrik W. Zaunbrecher is very grateful for financial support from the Gesellschaft für experimentelle Wirtschaftsforschung e.V. (GfeW) through the Heinz Sauermann-Förderpreis zur experimentellen Wirtschaftsforschung. Nickolas Gagnon is also grateful for financial support from the Fonds de recherche du Québec - Société et culture. We thank Jona Linde, Jan Potters, Arno Riedl, and participants at TIBER 2018 and in the MLSE seminar in Maastricht for helpful comments and suggestions. Authors information: Henrik W. Zaunbrecher: Maastricht University, Department of Economics, P.O. Box 616, 6200 MD Maastricht, The Netherlands, h.zaunbrecher@maastrichtuniversity.nl; Nickolas Gagnon: Maastricht University, Department of Economics, P.O. Box 616, 6200 MD Maastricht, The Netherlands, n.gagnon@maastrichtuniversity.nl.
} 


\section{Introduction}

The carriers of value or utility are changes rather than final asset positions

- Kahneman and Tversky (1979), Prospect Theory: An Analysis of Decision under Risk

Heterogeneous income growth has been identified as a central issue of our times (Milanovic, 2016, Piketty, 2014). For instance, in the United States between 1980 and 2004, pre-tax real incomes have increased by $121 \%$ for the richest $10 \%$, by $42 \%$ for the richest $10-50 \%, 7 \%$ for the richest $50-80 \%$, and decreased by $25 \%$ for the poorest $20 \%$ (Piketty et al. 2018). Comparable pictures emerge in other countries, more moderate in Europe and more extreme in Asia (Alvaredo et al., 2017). 1 Moreover, factors affecting individuals' redistribution preferences are a major topic for economists and policymakers. For example, studies have shown the influence of income inequality, especially disadvantageous inequality (e.g., Fehr and Schmidt, 1999; Bolton and Ockenfels, 2000) 2 Surprisingly, no study has investigated the possible role of income changes on redistribution decisions. However, there are reasons to believe that decreasing incomes may affect redistribution decisions.

Studies have provided evidence that individuals are especially averse to losses relative to a reference state (e.g., Kahneman and Tversky, 1979, Genesove and Mayer, 2001, and Rizzo and Zeckhauser, 2003) and that they dislike decreasing wage trends (Loewenstein and Sicherman, 1991). One might be especially irate at an absolute or even relative wage decrease and seek compensation for it-irrespective of the income inequality engendered by the wage change. However, whether this is indeed the case or not is still unknown because income changes in observational data are intertwined with a myriad of potentially confounding factors, such as levels of income inequality and geographical or socio-demographic differences between those with increasing and decreasing incomes. We

\footnotetext{
${ }^{1}$ Some of this heterogeneity is spatial: Against the backdrop of economic growth at the national level, several major industrial hubs experienced striking declines in average household incomes since the 1970s, e.g., Buffalo $(-23 \%)$, Cleveland (-32\%), and Detroit (-35\%) (Hartley, 2013). Other differences in the evolution of incomes can be observed in the U.S., e.g., between college educated and non-college educated (Goldin and Katz 2007), between men and women (Blau and Kahn, 2017), and between Caucasians and AfricanAmericans (Bayer and Charles, 2018).

2 Fisman et al. (2017), Kerschbamer and Müller (2020), Epper et al. (2020), and Almås et al. (2020) show that elicited social preferences correlate with political support for redistributive policies at the societal level.
} 
therefore isolate the role of income changes on redistribution decisions in an experiment, a common methodology for examining redistributive decisions.

We designed a laboratory experiment in which individuals complete real-effort tasks for wages that are exogenously assigned to them. The treatments that we implement vary the intra-personal and inter-personal wage changes faced by two matched participants over multiple periods. The wages are taxed and, after each treatment, each of the two participants individually decides how the money deducted from the wages of both participants is redistributed among them. We then implement one decisions per matched pair of participants. Crucially, we keep income inequality fixed in all treatments, only varying the wage changes. This feature allows us to make causal inferences between wage decreases and redistribution behavior.

Our contention that wage decreases can influence redistribution decisions is rooted in the large number of studies documenting different forms of reference dependence as well as loss aversion. Research on reference-dependent preferences has long modeled the dislike of individuals for losses relative to an intra-personal reference state (Kahneman and Tversky, 1979; Tversky and Kahneman, 1991; Kőszegi and Rabin, 2006). Empirical research suggests that the behavior of workers is consistent with a dislike for falling behind one's earnings goals (Camerer et al., 1997; Crawford and Meng, 2011), behind one's expectations (Mas, 2006; Abeler et al., 2011), and behind one's own past income (DellaVigna et al., 2017; Cohn et al., 2015). Loewenstein and Sicherman (1991) also report that individuals prefer increasing wage profiles to equivalent decreasing ones 3 Similarly, self-reported well-being is lower when one's living standard decreases over time (Clark et al., 2008, Senik, 2009). Nevertheless, none of these studies analyze the impact of wage decreases on redistribution decisions.

Moreover, inequality aversion models (Fehr and Schmidt, 1999; Bolton and Ockenfels, 2000) posit that individuals dislike to have less than others. In other words, individuals

${ }^{3}$ The same effect has been shown for other contexts such as experiences (Ross and Simonson, 1991), environmental outcomes (Guyse et al. 2002), and health (Chapman. 1996). 
dislike to fall behind an inter-personal reference point, i.e., falling behind others 4 This literature often studies inequality aversion in contexts where income changes and income inequality are bundled together. For instance, Cohn et al. (2014), Breza et al. (2017), and Dube et al. (2019) study the effect of wage inequality on labor decisions, in a context where wage inequality appears after a period of wage equality between workers. Similarly, Kuhn et al. (2011) analyze changes in consumption after one's neighbor wins at a lottery. However, these studies cannot isolate the effect of wage changes from the effect of the income inequality that they create.

Key to our investigation is the causal relationship that we obtain between wage decreases and redistribution decision, which is provided by the highly-controlled environment of a laboratory experiment. This methodology provides three main advantages. First, we randomly assign wage changes, which precludes that individuals experiencing different changes do so because of different underling characteristics. Second, crucially, we can study wage changes without changing the overall income inequality. That is, we clearly separate the role of income decreases from the role of disadvantageous income inequality. Third, our design rules out a role of expectations regarding future wages that income changes might naturally create, which in return is likely to affect redistribution decisions (Bénabou and Ok, 2001; Alesina and La Ferrara, 2005).

Overall, we find evidence that individuals behave more selfishly when they experience decreasing wages. Pooling together participants who earn more (High Earners) and participants who earn less (Low Earners), we find that they share significantly less when they face decreasing wages than other types of wage trends that we explore. Specifically, High Earners share significantly less with the other participant following an intra- or an inter-personal

\footnotetext{
${ }^{4}$ These models also posit that individuals dislike to have more than others, although to a lesser extent than they dislike to have less. We focus on disadvantageous inequality here for two reasons. First, disadvantageous inequality is assumed to be stronger in these models and a large number of empirical studies have gathered evidence supporting its existence. Second, our research is closely linked to research on loss aversion, which considers that individuals are especially sensitive to losses. The empirical evidence includes observational research (Clark and Oswald 1996, Solnick and Hemenway | 1998, Luttmer| 2005), natural experiments (Kuhn et al. 2011, Card et al. 2012), field experiments (Cohn et al. 2014, Breza et al. 2017, Dube et al. 2019) as well as laboratory experiments (Fehr and Schmidt, 1999, Bolton and Ockenfels, 2000) and experiments with the general population (Bellemare et al. 2008 ).
} 
reduction in their wages. Low Earners share less after a combined intra- and inter-personal decline in their wage, although only at marginally significant levels. The effect is modest in size (approximately $-6 \%$ to $-8 \%$ ), perhaps due to the limited time span of our experiment. We do not find statistical differences between the effects of intra- and inter-personal wage decreases. Our results suggest that declining absolute or relative wages could contribute to the support for redistributive policies aiming to rectify those declines.

The rest of the paper is structured as follows: First, we introduce the experimental design. Second, we advance the hypotheses. Third, we present the empirical analyses and the results. Fourth, we conclude by briefly discussing implications of our findings for the literature and for public policies.

\section{Experimental Design}

Our experiment consists of five periods. In a period, two participants are anonymously matched together. A period consists of two sub-periods in which participants perform a real-effort task and ends with a redistribution decision.

The effort task in every sub-period is to reduce the size of four circles on the computer screen until they disappear. This is done by repeatedly clicking on a circle with the mouse while it moves across the screen. Only one circle appears at the time, and each click on it slightly decreases its size. A new circle appears once a circle completely disappears ${ }^{5}$ Participants have four minutes to complete the task, which can be completed easily by exerting a reasonable effort (most participants take approximately two minutes to finish the task). They are provided with a countdown and with a record of how many circles they have completed so far. Figure 1 provides a screenshot of the task as experienced by participants in sub-period 2. Note that, in the experiment, we call circles "balls" and that we provide participants with the reminder that they need to reach a "Ball Threshold" of four to indicate that they need to make four circles disappear in order to earn the wage.

\footnotetext{
${ }^{5}$ Participants are not paid more if they complete more than four circles. The task is a modified version of the one developed by Cacault and Grieder (2016).
} 


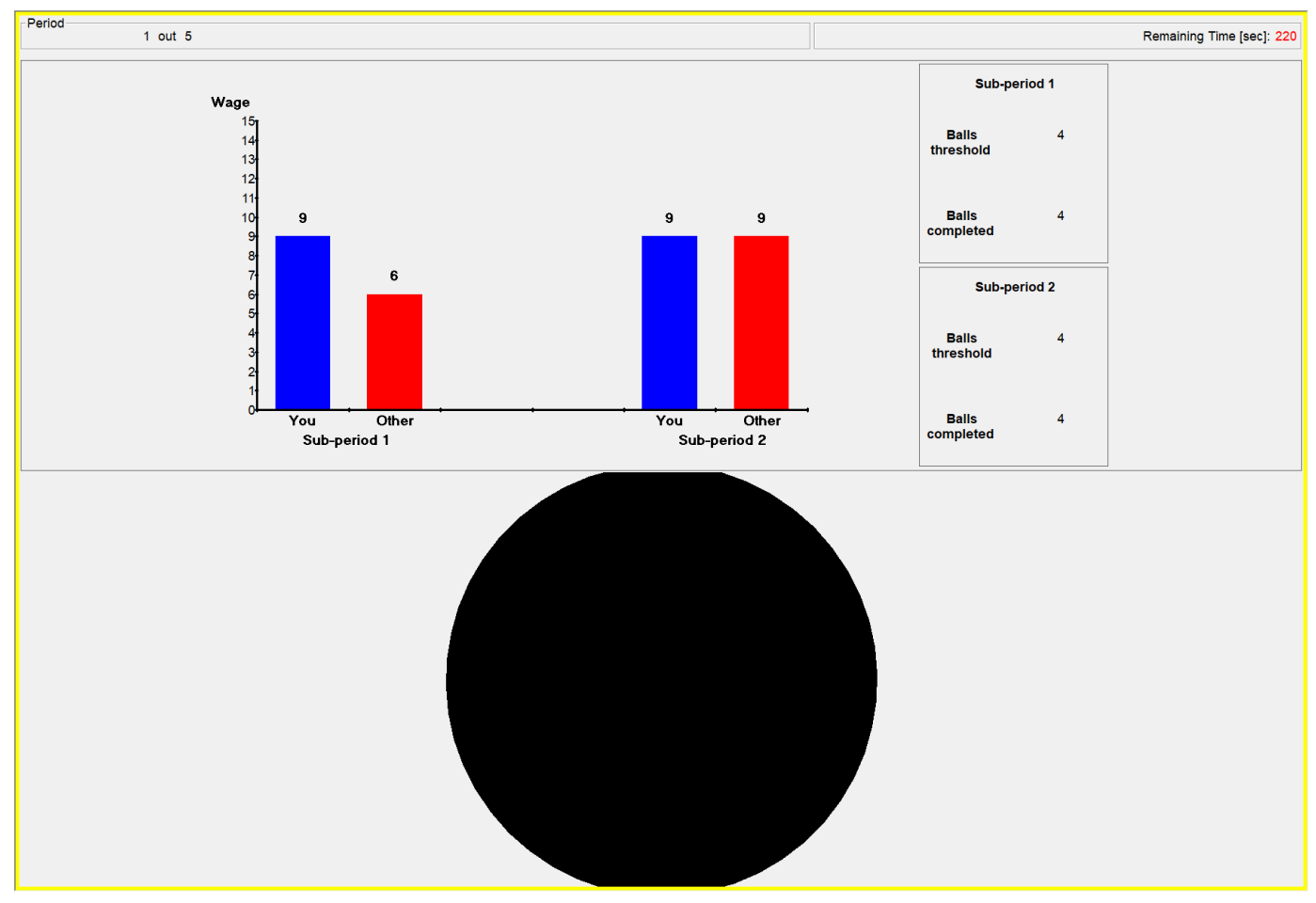

Figure 1: Screenshot of task in sub-period 2 (CATCHING UP treatment)

At the start of a period, participants are informed of their wage for the first sub-period a few seconds before the first sub-period starts. During a period, they monitor how their own wage and the wage of their matched partner evolve over the two sub-periods. This information is visualized through one graph exhibiting one's own wages and the wages of the other participant over the period up to the current sub-period. That is, participants see the wages in the current sub-period, and if they are in the second sub-period, they also see the wages from the previous sub-period. In addition to providing a screenshot of the task, Figure B.1 also shows how participants observe the evolution of wages in sub-period 2. The screen presents the wage information from the first sub-period on the left part of the graph, and from the second sub-period on the right part of the graph. Participants have an additional minute to rest in between the two sub-periods. A few seconds before the second sub-period starts, they are informed about any wage changes that occur between the sub-periods. 
The participants are paid the two wages of a period-one for each of the two subperiods-if and only if they complete the task in both sub-periods 6 A third of each wage that they earn during the two sub-periods is taken from them and placed in a joint account. That is, the joint account contains a third of the two wages of one participant, and a third of the two wages of the other participant $]^{7}$

At the end of each period, the two participants individually propose how to distribute the money contained in the joint account, which has been collected from their wages for the two sub-periods. This is implemented through a dictator game with role uncertainty. That is, one of the two choices is randomly chosen to count. The money in the joint account always amounts to 11 Euro. Participants can keep the entire joint account for themselves, transfer its content to the other participant, or chose any in-between allocation in increments of 10 cents $\sqrt[8]{ }^{8}$ Participants then take a two-minute break before the next period starts. At the end of the experiment, one of the two participants' choices from one period is randomly chosen to count for payment.

We employ five treatments that we implement for each participant over the five periods. The treatments vary the wage changes faced by participants between the first and second sub-period of a period. A participant is always in the role of either the High Earner or the Low Earner ${ }^{9}$ In the first role (High Earner), a participant always experiences advantageous income inequality over the period. The sum of the two wages in a period is always 18 Euro. Similarly, the Low Earner always faces disadvantageous income inequality over the period - the sum of the two wages is always 15 Euro. Crucially, this allows us to maintain the same income inequality over the period in all treatments, such that income inequality cannot explain any treatment differences ${ }^{10}$

We chose a within-subject design in order to increase statistical power (Bellemare et al., 2016). Table 1 details the wages of Low Earners and High Earners over the two sub-periods

\footnotetext{
${ }^{6} \mathrm{~A}$ participant is paid nothing for a period if the task in one of the two sub-periods is not completed. However, we set the wage high enough relative to the effort required for the task so that this only affected 2 out of 298 participants. We excluded these participants and their matched participants because the matched participants could see that those did not complete the task. Therefore, a total of 4 participants were dropped for the data analysis.

${ }^{7}$ To ease the explanation for participants, we phrase the parts of the income taken as taxes and the distribution
} 
Table 1: Treatments overview

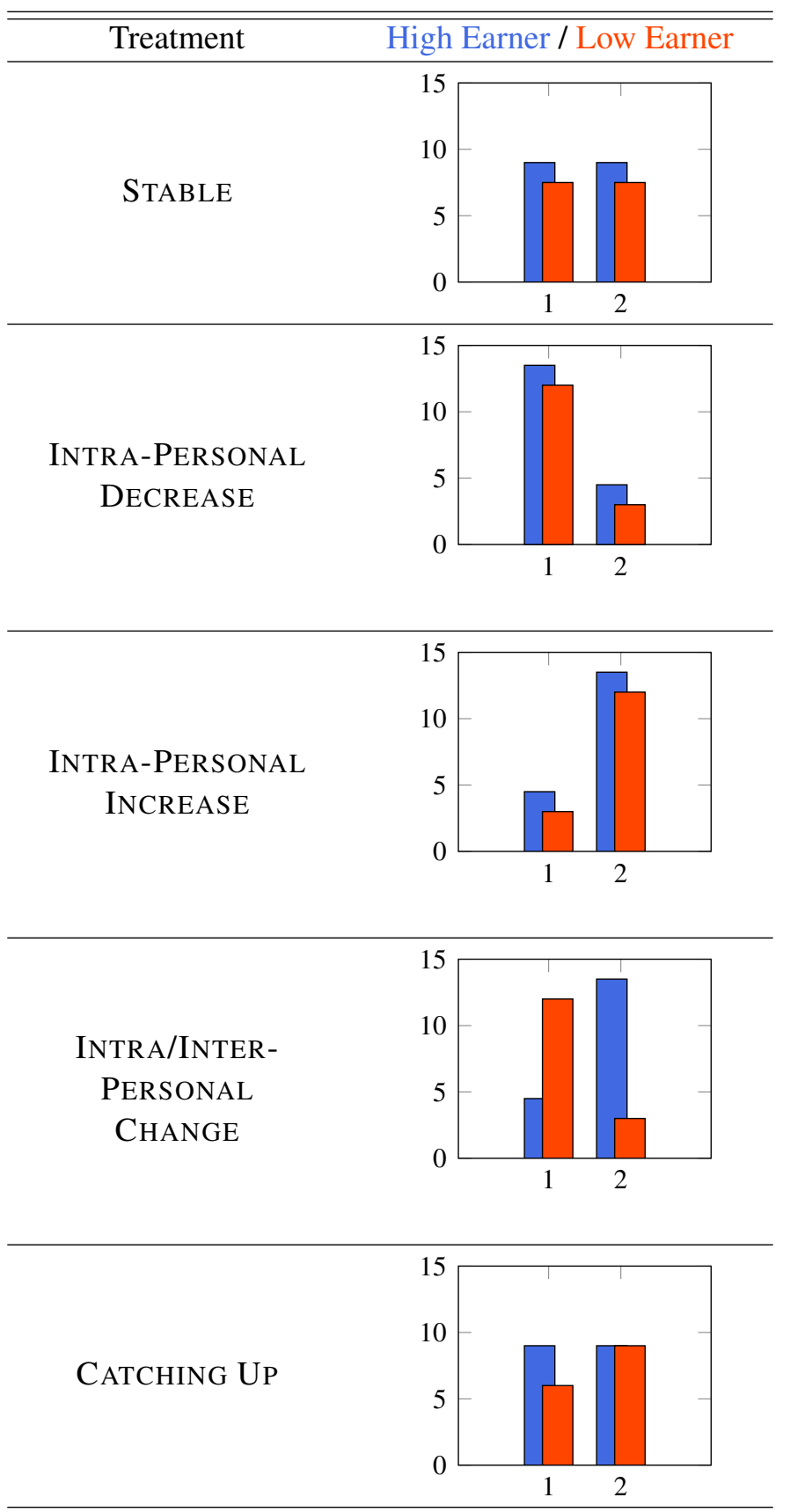

Wages are indicated on the vertical axis in Euro, and the two subperiods of a period are indicated on the horizontal axis. Income inequality is constant over the period: incomes are 15 Euro for the Low Earner and 18 Euro for the High Earner. 
in the five treatments. The order of treatments is randomized 11 As we are interested in studying individual responses to absolute and relative wage decreases, we designed the following treatments varying wages changes. Note that while those treatments do not cover the whole universe of possible wage changes, they do provide a diverse set of them to study possible effects of declining wages. Those include stable wages as well as an increasing wage profile. In STABLE, the wage of each participant remains constant in the two sub-periods. In Intra-Personal Decrease and Intra-Personal InCREase, both participants face either an absolute wage increase or decrease. This allows us to study the effects of intra-personal wage changes. In InTRA/InTER-PERsonal CHANGE, the Low Earner experiences a wage decrease while the High-Earner experiences a wage increase. The wage changes are therefore both absolute and relative for the two participants. In CAtching Up, the wage of the Low Earner increases, while the wage of the High Earner is constant. That is, the High Earner encounters a relative wage decrease-the Low Earner is "catching up" with the High Earner.

Before starting the experiment, the experimenter reads the instructions aloud and participants are provided with a written copy detailing all steps of the experiment ${ }^{12}$ After reading the instructions, participants complete comprehension questions, and help is provided if needed. They also go through a practice period, which is a shorter version of a real period, so that they become familiar with the proceedings of a period. This practice period includes the task and the redistribution decision, but does not count for payment. In it, each participant has the same wage, which stays constant of the two sub-periods.

decisions as a redistribution of taxes collected.

${ }^{8}$ Appendix 5 provides a screenshot showing how the redistribution decision is presented to participants.

${ }^{9}$ Participants are not informed that they stay in their role for the experiment.

${ }^{10} \mathrm{~A}$ possible alternative design could have been to impose income equality over the period in all treatments. However, we found it natural to create income inequality over each period, as income inequality is common outside of the laboratory.

${ }^{11}$ There are 120 possible orders (5!). We overly sample from a random subset of the orders due to a software problem. That is, approximately $70 \%$ of the orders are randomly drawn from a random subset of 30 ordersthe subset itself is a random selection from the 120 orders-and the remaining $30 \%$ is randomly drawn from the 90 other orders. Conducting the data analysis separately for each of those two sub-samples qualitatively provides the same results.

${ }^{12}$ We provide the original instructions as well as important screenshots of the experiment in the Appendix. 
In terms of participant matching, participants are informed that they are paired with a participant in the same laboratory session in each period. The experiment was designed using the software z-Tree (Fischbacher, 2007). It was conducted at the BEElab (Behavioural and Experimental Economics Laboratory) of Maastricht University. Our sample consists of 294 participants recruited over 16 sessions via the online recruitment software ORSEE (Greiner, 2015), 13 The experiment lasted for about 90 minutes and participants earned 16.50 Euro on average.

\section{Hypotheses}

We posit that, if individuals face a wage decrease, they experience disutility and take from others to be compensated. We also assume that two forms of disutility are created by wage decreases. The first is intra-personal disutility created from an absolute wage decrease. Individuals are loss averse with respect to their past wage. That is, they take their past wage as the reference state, and deviations below this reference point create disutility. The second is inter-personal disutility created from a relative wage decrease. Individuals take the wage change of others as the reference state and they are loss averse with respect to this change-a decrease relative to the wage changes of others creates disutility. We do not explicitly model this process. Rather, we directly test whether individuals give less or take more from others when they experience intra- and inter-personal declining wages.

High Earners face an absolute wage decrease in INTRA-PERSONAL DECREASE and a relative wage decrease in CATCHING UP. In contrast, they experience no decrease in Stable, Intra-Personal Increase, and Intra/Inter-Personal Change. We therefore predict the following, which does not distinguish between absolute and relative wage decrease.

Hypothesis 1. High Earners give less in InTRA-Personal DeCREASE and CATChInG UP than in StABle, INTRA-PERSONAL INCREASE, and INTRA/INTER-PERSONAL

\footnotetext{
${ }^{13}$ See footnote 6 explaining that four additional participants are not counted in our sample.
} 


\section{CHANGe.}

Low Earners encounter an absolute wage decrease in INTRA-PERSONAL DECREASE and an absolute and relative decrease in INTRA/InTER-PERsonal Change. In contrast, their wage is constant in the STABLE treatment. Moreover, they experience no wage decrease in Intra-Personal Increase and CATChing Up. We posit that Low Earners compensate their absolute and relative decreasing wage by taking more from others, and therefore make the following predictions for them.

Hypothesis 2. Low Earners give less in InTRA/Inter-Personal Change and InTRAPersonal Decrease than in Stable, Intra-Personal Increase, and Catching UP.

Low Earners face an absolute decrease as well as a relative wage decrease only in INTRA/INTER-PERSONAL ChANGE, and at most an absolute decrease in the other treatments. Therefore, we also make the following prediction.

Hypothesis 3. Low Earners give less in INTRA/INTER-PERSONAL CHANGE than in INTRAPersonal Decrease, Stable, Intra-Personal Increase, and Catching Up.

Similarly, since for Low Earners there is only an absolute income decrease in INTRAPERSONAL DECREASE, we make the following more precise prediction-which isolates the additional effect of relative income decrease.

Hypothesis 4. Low Earners give less in INTRA/INTER-PERSONAL CHANGE than in INTRAPERSonAl Decrease.

In addition, Hypotheses 2-4 taken together imply a specific ordering of the treatments, namely that Low Earners give less in INTRA/INTER-PERSONAL CHANGE than in INTERPersonal Decrease, and less in Inter-Personal Decrease than in Stable, InterPersonal InCREASE, and CATChing UP. Thus we can also test these hypotheses jointly. 


\section{Results}

We first provide summary statistics and then test our hypotheses. Then we report the results of two robustness check: 1 . Only considering participants who give at least once, and 2. Dropping those individuals who give almost everything.

\section{Summary Statistics}

Table 2 presents the average amount from the 11-Euro joint account that participants give to the other participant. We provide the data for all participants and then for those participants whom we call non-selfish, i.e., they give a positive amount in at least one period. Overall, if we look at all participants, we see that mean giving is 1.53 Euro ( $\mathrm{SD}=2.23$ Euro) or $14 \%$ of the joint account. High Earners are generally less generous than Low Earners. High Earners appear to be slightly less generous in the CATChing UP and InTRA-PERSONAL DECREASE treatments. Low Earners are less generous in InTRA/InTER-PERsonAl ChANGE than in other treatments. If we only look at the non-selfish participants, we observe the same patterns.

Compared to dictator games in general, average giving in our experiment is on the lower side of the spectrum found in the literature (see meta-study by Engel (2011) and comment by Zhang and Ortmann (2014); average giving in the dictator game is $28.3 \%$ ). Factors present in our study can considerably reduce generosity, namely using a student sample, endowing recipients, repeating the game, dictators earning the money that they can redistribute, and the option of taking money from others. Moreover, role uncertainty about who will give and who will receive has also been shown to increase pro-sociality in dictator games (Iriberri and Rey-Biel, 2011).

Figure 2 shows the cumulative distribution of the amounts given, separately for High Earners and Low Earners. There is extensive lower-bound censoring: Participants give nothing in 56\% of decisions (59\% for High Earners, 53\% for Low Earners). Thus, the low average sharing across treatments is strongly driven by the large number of participants exhibiting fully selfish behavior. Moreover, participants share no more than 1 Euro in $68 \%$ 
Table 2: Summary statistics

\begin{tabular}{|c|c|c|c|c|}
\hline \multirow[b]{3}{*}{ Treatment } & \multicolumn{4}{|c|}{ Amount given } \\
\hline & \multicolumn{2}{|c|}{ All participants } & \multicolumn{2}{|c|}{ Non-selfish participants } \\
\hline & $\begin{array}{c}\text { High Earners } \\
\text { Mean (SD) }\end{array}$ & $\begin{array}{c}\text { Low Earners } \\
\text { Mean (SD) }\end{array}$ & $\begin{array}{l}\text { High Earners } \\
\text { Mean (SD) }\end{array}$ & $\begin{array}{c}\text { Low Earners } \\
\text { Mean (SD) }\end{array}$ \\
\hline Stable & $\begin{array}{c}1.62 \\
(2.35)\end{array}$ & $\begin{array}{c}1.49 \\
(2.18)\end{array}$ & $\begin{array}{c}3.05 \\
(2.46)\end{array}$ & $\begin{array}{c}2.46 \\
(2.34)\end{array}$ \\
\hline INTRA-PERSONAL & 1.57 & 1.48 & 2.96 & 2.45 \\
\hline DECREASE & $(2.42)$ & $(2.15)$ & $(2.64)$ & $(2.31)$ \\
\hline INTRA-PERSONAL & 1.63 & 1.45 & 3.07 & 2.40 \\
\hline INCREASE & $(2.39)$ & $(2.13)$ & $(2.53)$ & $(2.30)$ \\
\hline INTRA/INTER-PERSONAL & 1.62 & 1.42 & 3.06 & 2.35 \\
\hline CHANGE & $(2.34)$ & $(2.03)$ & $(2.44)$ & $(2.15)$ \\
\hline \multirow[t]{2}{*}{ CATCHING UP } & 1.41 & 1.58 & 2.65 & 2.61 \\
\hline & $(2.20)$ & $(2.15)$ & $(2.42)$ & $(2.23)$ \\
\hline $\bar{N}$ & 147 & 147 & 78 & 89 \\
\hline
\end{tabular}

Note: Participants could give any amount between 0 and 11 Euro from the 11-Euro joint account. The remaining amount was credited to their own account.

of decisions.

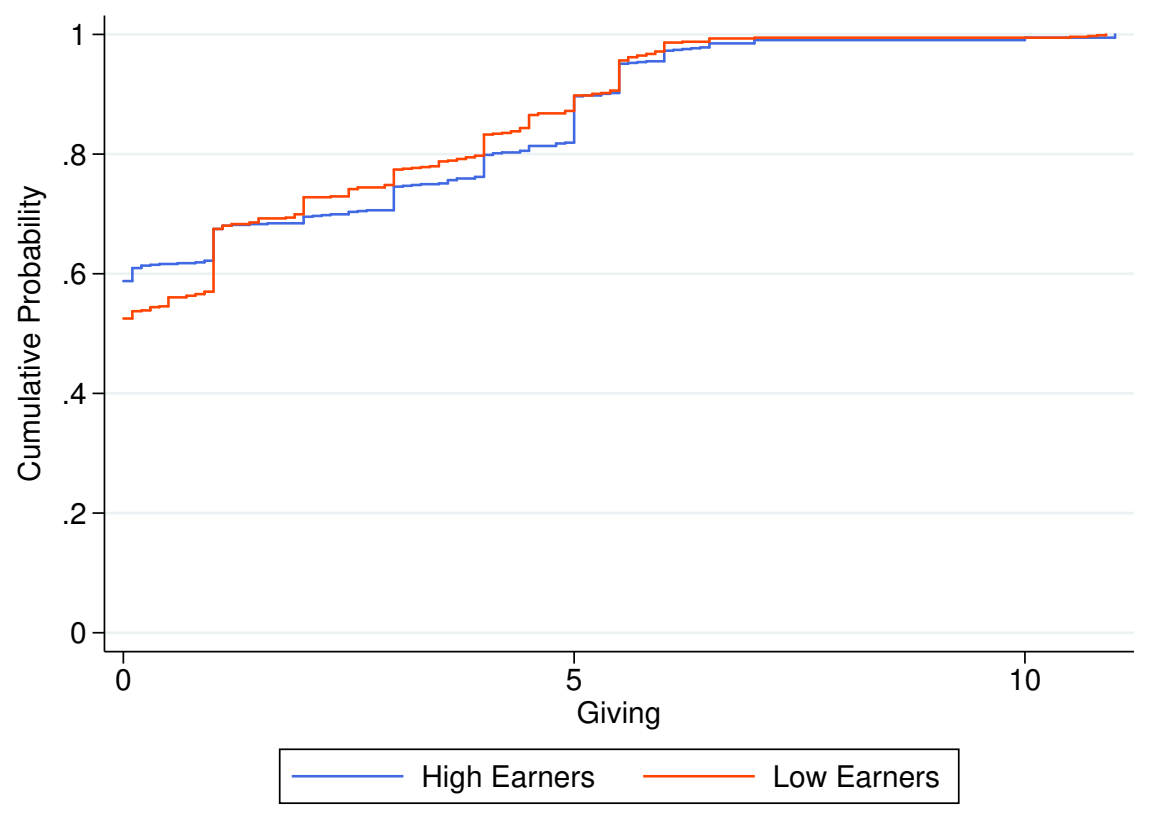

Figure 2: Cumulative distribution functions of giving 


\section{Hypothesis Testing}

Table 3 reports non-parametric tests of each of our four hypotheses. The upper part concerns High Earners (Hypothesis 1); the lower part concerns Low Earners (Hypotheses 2-4). The tests that we employ are mostly Wilcoxon signed-rank tests (WSR). We also make use of the rank-based Page test (Page, 1963), in which the null hypothesis is that the amount given is the same in all treatments, whereas the alternative hypothesis is that the amount given follows a pre-specified treatment order. When we compare sets of treatments, we compare average giving per individual in one set of treatments with average giving per individual in the other set of treatments. Since our hypotheses are directed, we always use one-sided tests in the predicted direction. ${ }^{14}$

For High Earners we predicted in Hypothesis 1 that those experiencing the decreasing absolute or relative wage-in the treatments INTRA-PERSONAL DECREASE and CATCHING UP-would give less to the other participant, compared to what they give in the combined other treatments. We find that, indeed, those High Earners whose wage decreased over the period become less generous. As indicated in the first row of Table 3, the effect is significant at the $5 \%$ level (WSR $p$-value $=0.017$ ). Moreover, although not presented in the table, we cannot statistically distinguish between the effects of intra- and inter-personal wage decreases on giving (Intra-Personal Decrease vs. Catching Up, WSR $p$ value $=0.458)$. We can also analyze the effect of the two decreasing-wage treatments separately. The reduction in giving induced by an intra-personal wage decrease (INTRAPersonal Decrease) and the reduction in giving induced by an inter-personal wage decrease (CATCHING UP) relative to the treatments without any wage decreases are both significant $(\mathrm{WSR} p$-value $=0.007 ; \mathrm{WSR} p$-value $=0.001$, respectively $)$.

\footnotetext{
${ }^{14} \mathrm{To}$ account for censoring and to provide a parametric alternative specification, we also conducted randomeffects Tobit regressions, which employ a dummy for the set of treatments of interest and combine the other treatments in the baseline. However, we rely on the non-parametric results for our analysis because an inspection of the residuals of an equivalent linear regression suggests a violation of the assumption that standard errors are normally distributed aside from the violation created by the lower-bound censoring. In addition, Table C.2 of the Appendix C details the regression specifications for the Tobit regressions. For completeness, Appendix Calso reports results from random-effects Tobit regressions where we include individual treatment dummies and employ the STABLE treatment as reference group.
} 
Table 3: Tests of hypotheses

\begin{tabular}{|c|c|c|c|}
\hline & High Earners & $\begin{array}{l}\text { Change in } \\
\text { giving }\end{array}$ & $\begin{array}{l}\text { One-sided } \\
p \text {-value }\end{array}$ \\
\hline H1 & $\begin{array}{r}\text { CATCHING UP, } \\
\text { INTER-PERSONAL DECREASE }< \\
\text { StABLE, } \\
\text { INTER-PERSONAL INCREASE, } \\
\text { InTRA/INTER-PERSONAL CHANGE }\end{array}$ & $\begin{array}{c}-0.14 \text { Euro } \\
(-8.38 \%)\end{array}$ & 0.017 \\
\hline & Low Earners & & \\
\hline $\mathrm{H} 2$ & $\begin{array}{r}\text { INTRA/INTER-PERSONAL CHANGE, } \\
\text { INTRA-PERSONAL DECREASE }< \\
\text { STABLE, } \\
\text { INTRA-PERSONAL INCREASE, } \\
\text { CATCHING UP }\end{array}$ & $\begin{array}{c}-0.05 \text { Euro } \\
(-3.61 \%)\end{array}$ & 0.101 \\
\hline $\mathrm{H} 3$ & $\begin{array}{r}\text { INTRA/INTER-PERSONAL CHANGE }< \\
\text { STABLE, } \\
\text { INTRA-PERSONAL DECREASE, } \\
\text { INTRA-PERSONAL INCREASE, } \\
\text { CATCHING UP }\end{array}$ & $\begin{array}{c}-0.08 \text { Euro } \\
(-5.33 \%)\end{array}$ & 0.052 \\
\hline $\mathrm{H} 4$ & $\begin{array}{r}\text { INTRA/INTER-PERSONAL CHANGE }< \\
\text { INTRA-PERSONAL DECREASE }\end{array}$ & $\begin{array}{c}-0.06 \text { Euro } \\
(-4.22 \%)\end{array}$ & 0.484 \\
\hline $\begin{array}{r}\text { Joint } \\
\mathrm{H} 2-4\end{array}$ & $\begin{array}{r}\text { Intra/InTER-Personal Change }< \\
\text { InTER-Personal DeCREASE }< \\
\text { Stable, Inter-Personal InCREASE, CATCHING Up }\end{array}$ & & 0.076 \\
\hline
\end{tabular}

Note: Change in giving corresponds to the difference in Euro and percentage distributed to the other participant from the 11-Euro joint account between different sets of treatments. In line with our directed nature of our hypotheses, for H1-4 we report one-sided $p$-values of non-parametric Wilcoxon signed-rank tests (WSR). Furthermore, we report the one-sided $p$-value for a joint test of H2-4. We use Page's test for ordered alternatives which evaluates whether population means follow a pre-specified order. For both WSR and Page tests, we average giving per individual over each of the two treatment sets under consideration.

For Low Earners, we formulated three hypotheses. Hypothesis 2 states that those participants who experienced wage decreases—in the treatments INTRA-PERSONAL DECREASE and InTRA/INTER-PERSONAL CHANGE-share less with the other participant, relative to 
the combined other treatments. We find only weak evidence that the combined decreasingwage treatments reduce the amount given (WSR $p$-value $=0.101)$. Then, Hypothesis 3 states that Low Earners who specifically experienced the combined intra- and inter-personal wage decrease-in treatment INTRA/INTER-PERSONAL CHANGE-become less generous than in all other treatments combined. Our tests find support for this contention at marginal significance levels $(\mathrm{WSR} p$-value $=0.052)$

Hypothesis 4-that Low Earners give less when facing the combined intra- and interpersonal wage decrease than when facing the intra-personal wage decrease-is not supported. That is, giving is not significantly lower in InTRA/INTER-PERSONAL CHANGE than in INTRA-PERSONAL DECREASE $(\mathrm{WSR} p$-value $=0.484)$.

Our three hypotheses regarding Low Earners (Hypotheses 2-4) can be combined into a single extensive hypothesis, which is reported in the last row of Table 3. We use a Page test to evaluate the null hypothesis that the amount given is the same in all treatments, relative to the alternative hypothesis that the amount given follows the pre-specified treatment order. When evaluated in this manner, we again find some (limited) evidence that Low Earners compensate their decreasing wage by giving less to the other participant ( $p$-value $=$ 0.076). Finally, Table E shows that we find strong evidence of the negative effect of decreasing wages on giving when we pool High Earners and Low Earners together, and evaluate whether they give less when they face decreasing absolute or relative wages $(p$-value $=$ $0.007)$.

Result 1. High Earners: Participants become more selfish when facing decreasing wages than other wage trends. This holds both for intra-personal wage decreases and for interpersonal wage decreases (supports Hypothesis 1).

Result 2. Low Earners: (a) Participants become more selfish when facing combined intrapersonal and inter-personal decreasing wages than when facing other wage trends-at marginally significant levels (supports Hypothesis 3). (b) The combined intra- and interpersonal wage decrease treatment and the intra-personal wage decrease treatment together only increase giving at near marginally significant levels (only qualitatively supports Hy- 
Table 4: Analysis for Low and High Earners pooled together

\begin{tabular}{ccc}
\hline \hline & $\begin{array}{c}\text { Change in } \\
\text { giving }\end{array}$ & $\begin{array}{c}\text { One-sided } \\
p \text {-value }\end{array}$ \\
\hline DECREASING $<$ OTHER & $\begin{array}{c}-0.10 \text { Euro } \\
(-6.09 \%)\end{array}$ & 0.007 \\
\hline
\end{tabular}

Note: Change in giving corresponds to the difference in Euro and percentage. The set DECREASING contains treatments CATCHING UP and INTRA-PERSONAL DECREASE for High Earners, and InTRA/INTER-PERsonal ChANGE and InTRA-PERsonal DECREASE for Low Earners. The set OTHER contains all treatments excluded from DECREASING for High and Low Earners. We report one-sided $p$-values of non-parametric Wilcoxon signed-rank test (WSR). Giving is averaged per individual over each of the two treatment sets under consideration.

pothesis 2), although (c) the (non-)effect of intra-personal wage decreases is statistically indistinguishable from the effect of the combined intra-personal and inter-personal decreasing wages (does not support Hypothesis 4).

We conduct two additional analyses. First, we consider whether our results are similar when we examine only participants who give at least once, i.e., whose behavior is not always censored. We do find very similar results (see Appendix D), which suggests that the effects are not driven by the censored nature of the data. Second, we check that our results are robust to dropping the rare individuals who give almost everything during a period (i.e., 9 Euro or more out of the 11-Euro joint account), which would result in greater earnings for the participant they are matched with than for themselves. We do this because those participants might have misunderstood the instructions (alternatively, they could also simply be very generous). The results are unchanged for High Earners, but for Low Earners only the joint test of the treatment order remains significant (see Appendix E). In sum, result 1 concerning High Earners hypothesis stands unaffected by both robustness checks, and results 2 concerning the Low Earners hypotheses is weakened when excluding very generous individuals.

Finally, we assess the magnitude of the effect of decreasing wages on giving. For a sim- 
ple evaluation, we employ the summary statistics contained in Table 2. First, for High Earners, average giving declines from around 1.62 Euro in the three treatments without decreasing wages to 1.49 Euro in the two treatments with decreasing wages (INTRA-PERSONAL Decrease and Catching Up). This corresponds to an effect size of 0.06 pooled standard deviations, but which still translates into an $8 \%$ reduction in giving. If we consider only non-selfish High Earners, giving declines from approximately 3.06 Euro to 2.85 Euro-an effect size of 0.08 pooled standard deviations, and a $7 \%$ reduction in giving. Second, for Low Earners, average giving goes from approximately 1.51 Euro in the three treatments without decreasing wages to 1.42 Euro in the treatment with decreasing intra- and interpersonal wages (INTRA/INTER-PERSONAL CHANGE) and 1.48 Euro in the treatment with decreasing intra-personal wages (InTRA-Personal DeCrease). Consequently, the reduction caused by INTRA/INTER-PERSONAL CHANGE corresponds to an effect size of 0.04 pooled standard deviations, and a $6 \%$ decrease. Furthermore, the picture we obtain from considering only Low Earners who are not completely selfish is nearly identical.

\section{Discussion}

In this study, we conducted an experiment designed to identify how decreases in wages causally affect redistribution behavior. We hypothesized that individuals would become more selfish when they experience intra- or inter-personal wage decreases, i.e., in absolute terms or relative to others. We find evidence that individuals indeed share less with others when they face decreasing wages.

We investigate the effect on High Earners as well as on Low Earners. We find more convincing evidence that the redistributive behavior of High Earners is affected by decreasing wages. For Low Earners, the evidence is qualitatively in the direction predicted, but on the border of marginal significance. Specifically, High Earners become significantly less generous when they face a wage decrease. This occurs both in the case of an intra-personal decrease and in the case of an inter-personal decrease. In comparison, Low Earners share less with others when they face the combined intra- and inter-personal wage decreases, al- 
though the effect is marginally significant. They do not become significantly less generous when they only experience an intra-personal wage decrease. All in all, we find that decreasing wages increase selfish redistribution decisions, even though income inequality remains unchanged in our experimental environment.

This carries several implications for the effect of inequality on redistributive behavior. For instance, not taking into account the specific effect of changes may lead us to understate the importance of decreasing wages on support for public policies-e.g., for individuals who are worse off compared to their previous situation or compared to others. Similarly, it may lead us to underestimate that individuals can support policies to fend off the rise of others who are catching up to them in terms of income. More generally, our findings highlight the role of reference points in redistribution decisions beyond static income inequality, a topic that has previously been neglected.

An alternative mechanism that can explain our finding that High Earners become less generous after facing decreasing wages is suggested by the literature on avoidance behavior in charitable giving (Dana et al., 2007; Andreoni et al., 2017; Grossman and Van Der Weele, 2017). That is, it is possible that Higher Earners in the experiment use their wage decrease as an excuse to justify being less generous while still maintaining a positive self-image.

In addition, we note that the wage decreases that participants encounter in the laboratory are very short lived and the wage differences small compared to the time frame and scale over which wage changes occur in the economy. In this sense, it is quite remarkable that even with small wage differences and relatively short time periods, we are able to find significant differences in redistribution decisions. As such, the small effect sizes that we measure are likely to be lower bounds on the effects of income trends on redistribution.

The main objective for future research on the topic could be be to investigate if increasing the duration and the wage differences indeed results in larger effects. For instance, one could conduct an experiment with a duration of several weeks or even months. As such, our study should be seen as first step for that type of studies. As additional avenues for future studies on the topic, one could also vary the identity of the reference group as sev- 
eral diverging income trends concern specific societal groups, such as ethnic minority and majority groups. That would allow one to study whether individuals react more strongly to relative wage decreases when the other person is an individual sharing their social identity or if the other person belongs to an opposing or outgroup. Furthermore, we only investigate the effect of decreasing wages on redistributive preferences when the redistribution is zero sum. But many fights over resources are arguably wasteful rent-seeking activities, so that studying the effect of wage decreases in more complex settings could also be a fruitful avenue. 


\section{References}

Abeler, J., Falk, A., Goette, L., and Huffman, D. (2011). Reference points and effort provision. American Economic Review, 101(2):470-92.

Alesina, A. and La Ferrara, E. (2005). Preferences for redistribution in the land of opportunities. Journal of Public Economics, 89(5-6):897-931.

Almås, I., Cappelen, A. W., and Tungodden, B. (2020). Cutthroat capitalism versus cuddly socialism: Are americans more meritocratic and efficiency-seeking than scandinavians? Journal of Political Economy, 128(5):1753-1788.

Alvaredo, F., Chancel, L., Piketty, T., Saez, E., and Zucman, G. (2017). World inequality report 2018. World Inequality Lab.

Andreoni, J., Rao, J. M., and Trachtman, H. (2017). Avoiding the ask: A field experiment on altruism, empathy, and charitable giving. Journal of Political Economy, 125(3):625-653.

Bayer, P. and Charles, K. K. (2018). Divergent paths: A new perspective on earnings differences between black and white men since 1940. Quarterly Journal of Economics, 133(3):1459-1501.

Bellemare, C., Bissonnette, L., and Kröger, S. (2016). Simulating power of economic experiments: the powerBBK package. Journal of the Economic Science Association, 2(2):157-168.

Bellemare, C., Kröger, S., and Van Soest, A. (2008). Measuring inequity aversion in a heterogeneous population using experimental decisions and subjective probabilities. Econometrica, 76(4):815-839.

Bénabou, R. and Ok, E. A. (2001). Social mobility and the demand for redistribution: the POUM hypothesis. Quarterly Journal of Economics, 116(2):447-487.

Blau, F. D. and Kahn, L. M. (2017). The gender wage gap: Extent, trends, and explanations. Journal of Economic Literature, 55(3):789-865. 
Bolton, G. E. and Ockenfels, A. (2000). ERC: A theory of equity, reciprocity, and competition. American Rconomic Review, 90(1):166-193.

Breza, E., Kaur, S., and Shamdasani, Y. (2017). The morale effects of pay inequality. Quarterly Journal of Economics, 133(2):611-663.

Cacault, M. P. and Grieder, M. (2016). How group identification distorts beliefs. SSRN Working Paper No. 2601712.

Camerer, C., Babcock, L., Loewenstein, G., and Thaler, R. (1997). Labor supply of New York City cabdrivers: One day at a time. Quarterly Journal of Economics, 112(2):407441.

Card, D., Mas, A., Moretti, E., and Saez, E. (2012). Inequality at work: The effect of peer salaries on job satisfaction. American Economic Review, 102(6):2981-3003.

Chapman, G. B. (1996). Expectations and preferences for sequences of health and money. Organizational Behavior and Human Decision Processes, 67(1):59-75.

Clark, A. E., Frijters, P., and Shields, M. A. (2008). Relative income, happiness, and utility: An explanation for the easterlin paradox and other puzzles. Journal of Economic Literature, 46(1):95-144.

Clark, A. E. and Oswald, A. J. (1996). Satisfaction and comparison income. Journal of Public Economics, 61(3):359 - 381.

Cohn, A., Fehr, E., and Goette, L. (2015). Fair wages and effort provision: Combining evidence from a choice experiment and a field experiment. Management Science, 61(8):1777-1794.

Cohn, A., Fehr, E., Herrmann, B., and Schneider, F. (2014). Social comparison and effort provision: Evidence from a field experiment. Journal of the European Economic Association, 12(4):877-898. 
Crawford, V. P. and Meng, J. (2011). New York City cab drivers' labor supply revisited: Reference-dependent preferences with rational expectations targets for hours and income. American Economic Review, 101(5):1912-1932.

Dana, J., Weber, R. A., and Kuang, J. X. (2007). Exploiting moral wiggle room: experiments demonstrating an illusory preference for fairness. Economic Theory, 33(1):67-80.

DellaVigna, S., Lindner, A., Reizer, B., and Schmieder, J. F. (2017). Reference-dependent job search: evidence from Hungary. Quarterly Journal of Economics, 132(4):1969-2018.

Dube, A., Giuliano, L., and Leonard, J. (2019). Fairness and frictions: The impact of unequal raises on quit behavior. American Economic Review, 109(2):620-63.

Engel, C. (2011). Dictator games: A meta study. Experimental Economics, 14(4):583-610.

Epper, T., Fehr, E., and Senn, J. (2020). Other-regarding preferences and redistributive politics. University of Zurich, Department of Economics, Working Paper, (339).

Fehr, E. and Schmidt, K. M. (1999). A theory of fairness, competition, and cooperation. Quarterly Journal of Economics, 114(3):817-868.

Fischbacher, U. (2007). z-tree: Zurich toolbox for ready-made economic experiments. Experimental economics, 10(2):171-178.

Fisman, R., Jakiela, P., and Kariv, S. (2017). Distributional preferences and political behavior. Journal of Public Economics, 155:1-10.

Genesove, D. and Mayer, C. (2001). Loss aversion and seller behavior: Evidence from the housing market. Quarterly Journal of Economics, 116(4):1233-1260.

Goldin, C. and Katz, L. F. (2007). Long-run changes in the wage structure: narrowing, widening, polarizing. Brookings Papers on Economic Activity, (2):135-168.

Greiner, B. (2015). Subject pool recruitment procedures: organizing experiments with orsee. Journal of the Economic Science Association, 1(1):114-125. 
Grossman, Z. and Van Der Weele, J. J. (2017). Self-image and willful ignorance in social decisions. Journal of the European Economic Association, 15(1):173-217.

Guyse, J. L., Keller, L. R., and Eppel, T. (2002). Valuing environmental outcomes: Preferences for constant or improving sequences. Organizational Behavior and Human Decision Processes, 87(2):253-277.

Hartley, D. (2013). Urban decline in Rust-Belt cities. Federal Reserve Bank of Cleveland Economic Commentary, 2013-06.

Iriberri, N. and Rey-Biel, P. (2011). The role of role uncertainty in modified dictator games. Experimental Economics, 14(2):160-180.

Kahneman, D. and Tversky, A. (1979). Prospect theory: An analysis of decision under risk. Econometrica, 47(2):263-292.

Kerschbamer, R. and Müller, D. (2020). Social preferences and political attitudes: An online experiment on a large heterogeneous sample. Journal of Public Economics, $182: 104076$.

Kőszegi, B. and Rabin, M. (2006). A model of reference-dependent preferences. Quarterly Journal of Economics, 121(4):1133-1165.

Kuhn, P., Kooreman, P., Soetevent, A., and Kapteyn, A. (2011). The effects of lottery prizes on winners and their neighbors: Evidence from the Dutch postcode lottery. American Economic Review, 101(5):2226-47.

Loewenstein, G. and Sicherman, N. (1991). Do workers prefer increasing wage profiles? Journal of Labor Economics, 9(1):67-84.

Luttmer, E. F. (2005). Neighbors as negatives: relative earnings and well-being. Quarterly journal of economics, 120(3):963-1002.

Mas, A. (2006). Pay, reference points, and police performance. Quarterly Journal of Economics, 121(3):783-821. 
Milanovic, B. (2016). Global Inequality: A New Approach for the Age of Globalization. Harvard University Press, Cambridge, MA.

Page, E. B. (1963). Ordered hypotheses for multiple treatments: a significance test for linear ranks. Journal of the American Statistical Association, 58(301):216-230.

Piketty, T. (2014). Capital in the Twenty-First Century Century. Harvard University Press, Cambridge, MA.

Piketty, T., Saez, E., and Zucman, G. (2018). Distributional national accounts: methods and estimates for the United States. Quarterly Journal of Economics, 133(2):553-609.

Rizzo, J. A. and Zeckhauser, R. J. (2003). Reference incomes, loss aversion, and physician behavior. Review of Economics and Statistics, 85(4):909-922.

Ross, W. T. and Simonson, I. (1991). Evaluations of pairs of experiences: A preference for happy endings. Journal of Behavioral Decision Making, 4(4):273-282.

Senik, C. (2009). Direct evidence on income comparisons and their welfare effects. Journal of Economic Behavior \& Organization, 72(1):408-424.

Solnick, S. J. and Hemenway, D. (1998). Is more always better?: A survey on positional concerns. Journal of Economic Behavior \& Organization, 37(3):373-383.

Tversky, A. and Kahneman, D. (1991). Loss aversion in riskless choice: A referencedependent model. Quarterly Journal of Economics, 106(4):1039-1061.

Zhang, L. and Ortmann, A. (2014). The effects of the take-option in dictator-game experiments: a comment on engels (2011) meta-study. Experimental Economics, 17(3):414420. 


\section{A Instructions}

\section{Instructions}

Welcome to this economic experiment. Please read these instructions carefully. In the experiment, your decisions and the decisions of other participants will determine how much money you earn. You will be paid in cash at the end of the session, provided that you follow the rules. If you do not follow the rules, you will not be paid. You are forbidden from using your phone and from communicating with other participants at any time during the session. If you have any questions, please do not hesitate to raise your hand to ask the experimenter for help.

The session lasts for up to 90 minutes. You need to stay until the end to be paid. To complete the task in this experiment, you are also required to be able to click many times with a computer mouse (e.g., you need to have no injuries to your arms and fingers).

\section{General Instructions}

There are 5 periods, each lasting 8 minutes. Each period, you are matched with $\mathbf{1}$ anonymous other person. This can be any participant in the session. All participants work on the exact same task. Each period consists of 2 sub-periods of 4 minutes. In each sub-period, you are asked to complete a task to earn a wage. You need to complete the task in each of the 2 sub-periods in a period to earn the 2 wages for the period. Over the 2 sub-periods, you observe your wage and the wage of the other participant. Your wage and the wage of the other participant may vary over the 2 sub-periods, but the task stays the same.

In each of the 2 sub-periods, a tax is deducted from your wage and the wage of the other participant for this period. The tax is $1 / 3$ of the wage. You are left with the after-tax wages (wage minus tax). At the end of the period, the taxes that are taken from you and the other participant over the 2 sub-periods are joined together into the Total Tax Collected.

At the end of each of the 5 periods, you decide how to distribute the Total Tax Collected between you and the other participant. The other participant also decides how to distribute the Total Tax Collected. The decisions are anonymous. Either your distribution or the distribution of the other participant is randomly chosen to count for payment. If you do not complete the task for 1 of the 2 sub-periods for a period, then you do not earn anything in this period and you cannot choose a distribution in this period. The tax taken from the other participant is returned to him or her and there are no distribution decisions.

Until the end of the experiment, you do not receive feedback regarding what distribution the other participant chooses, and the other participant is not told what distribution you choose. Only at the end of the experiment, 1 of the 5 periods is randomly chosen to count for payment by the computer.

You are paid the following two parts for the chosen period. First, you are paid the $\mathbf{2}$ after-tax wages you earned in that period. Second, either your distribution of the Total Tax Collected or the distribution of the other participant you were matched with for this period is randomly chosen to be paid.

You need to answer a few comprehension questions and go through a Practice period before you start the experiment. In the next two sections, you are given more details regarding specific components of 
the experiment, and examples of how your wage and the wage of the other participant are presented during the experiment. Finally, a timeline summarizing the different steps is presented at the end of these instructions.

\section{Details}

Other Participant: The other participant is real and always works on the exact same task as you. $\mathrm{He}$ or she is someone else in the session. At the start of each period, you are matched with a participant for this period. That is, you are matched with the same participant for the 2 sub-periods of this period.

Periods: There are 5 periods, each lasting 8 minutes. Between every period, you have a 2-minute break to relax.

Sub-periods: Within every period, there are 2 sub-periods of 4 minutes each.

Task: The task is always exactly the same for every participant in every sub-period. It is a simple task that can be completed by exerting a reasonable effort. The task is to repeatedly click on a ball that appears on your computer screen. Every time you click on the ball, it decreases in size until it disappears. Click on the ball, and wait for it to move until you click again. If you click multiple times before it moves, the ball does not disappear faster. The minimum number of balls that need to disappear (Balls Threshold) in each sub-period to earn your wage is $\mathbf{4}$ balls. You need to reach this Ball Threshold in each of the 2 sub-periods of a period to earn the 2 wages for the period. This means that if you complete the task in only one of the 2 sub-periods of a period, you do not earn any of the 2 wages for the period. If you want, you can make more than $\mathbf{4}$ balls disappear, but this will not change your wage. That is, you cannot increase your wage by working more than meeting the Balls Threshold.

Wage and Tax: In a period, you earn two wages for completing the task: one wage in each of the two sub-periods. The wage may not be the same in the first sub-period and the second sub-period. If you do not complete the task in each of the $\mathbf{2}$ sub-periods, you are not paid at all for this period. That is, you neither earn the wage of the first sub-period nor the wage of the second sub-period. In each sub-period, a tax of $1 / 3$ is removed from your wage and from the wage of the other participant. The tax always amounts to $1 / 3$ of the wage, both for you and the other participant. You are left with the after-tax wage (wage minus tax).

Total Tax Collected: Taxes collected from you and from the other participant in the 2 sub-periods are added at the end of the period into the Total Tax Collected.

Distribution: At the end of each period, you choose how to distribute the money in the Total Tax Collected between yourself and the other participant. The other participant also decides how to distribute the Total Tax Collected. Either your distribution or the distribution chosen by the other participant is randomly chosen for payment, for the period randomly selected to be paid out. If you do not complete the task in sub-period 1 or 2 of a period, you cannot choose a distribution. In this case, the tax taken from the other participant is returned to him or her, and there are no distribution decisions. Similarly, if the other participant does not complete the task in one or both of the 2 sub-periods, you and the other 
participant do not make a distribution choice, and the tax collected on your wages is returned to you. The distribution decisions are anonymous and you are not informed about any of them before the end of the session.

Payment: At the end of the session, the computer randomly selects 1 period for payment. There are 2 parts to your payment, provided that you have completed the task in the 2 sub-periods of the chosen period. First, you receive your after-tax wage for each of the 2 sub-periods. Second, your distribution or the distribution of the other participant you were matched with in this period is randomly chosen and paid out. The randomly selected distribution is the only one you are informed about during the experiment. If you do not complete the task in each the $\mathbf{2}$ sub-periods of this period, you are paid nothing.

Comprehension Questions: You are asked a few comprehension questions before the experiment starts to make sure that you understand the instructions. If you do not understand a comprehension question, please ask the experimenter for help by raising your hand.

Practice Period: During the Practice period, you try the task and become familiar with the experiment, including the distribution decision. The practice period is shorter than the regular periods, and does not count for payment. The experiment starts after the practice period.

Questions: If anything is unclear, please do not hesitate to raise your hand to ask the experimenter. 


\section{Examples}

The following are three examples of how your wage and the wage of the other participant you are matched with for a period are indicated in each of the 2 sub-periods of a period.

Example 1: You are matched with a participant for the period. In sub-period 1, your wage is 3 EUR and the wage of the other participant is 4.5 EUR:

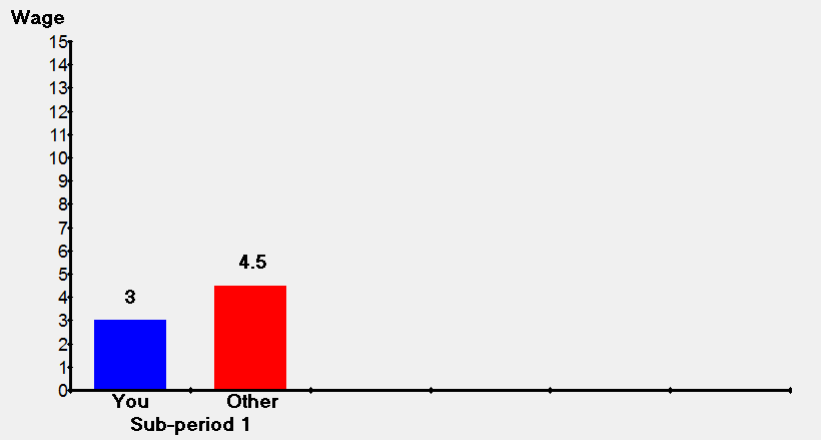

Then, in sub-period 2, your wage increases to 12 EUR and the other participant's wage increases to 13.5 EUR:

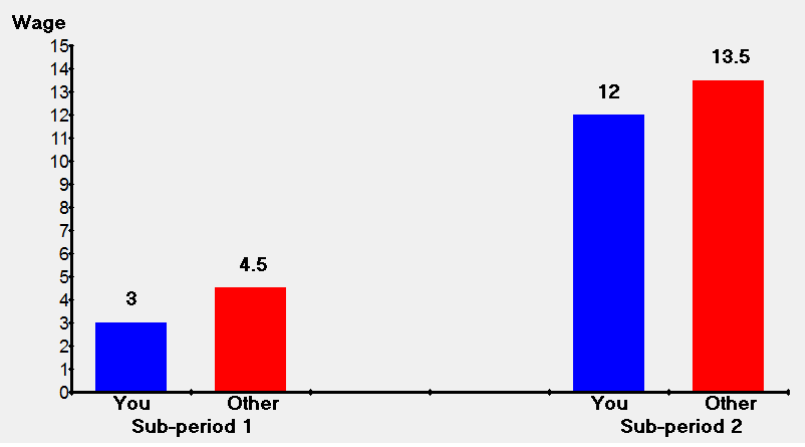


Example 2: You are matched with a participant for the period. In sub-period 1, your wage is 12 EUR and the wage of the other participant is 13.5 EUR:

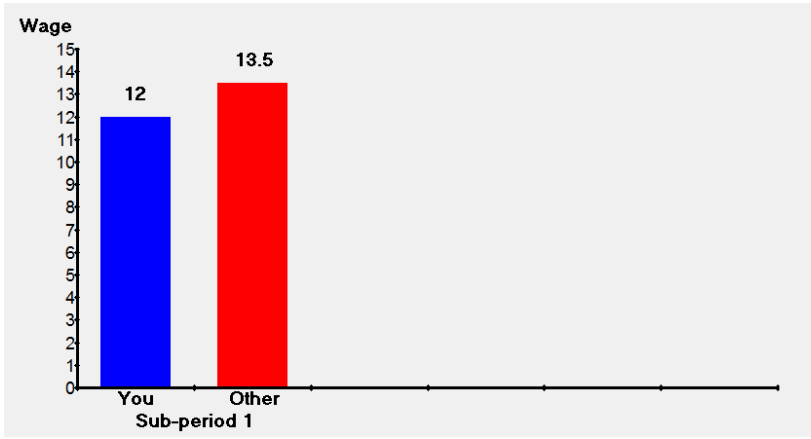

Then, in sub-period 2, your wage decreases to 3 EUR and the other participant's wage decreases to 4.5 EUR:

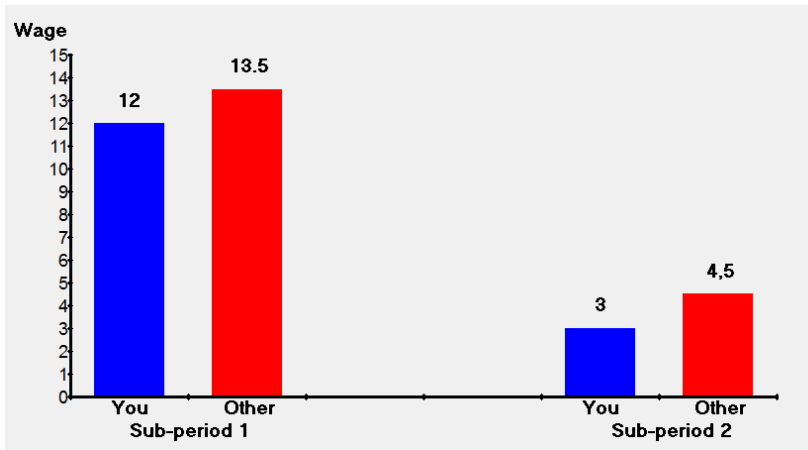


Example 3: You are matched with a participant for the period. In sub-period 1, your wage is 6 EUR and the wage of the other participant is also 6 EUR:

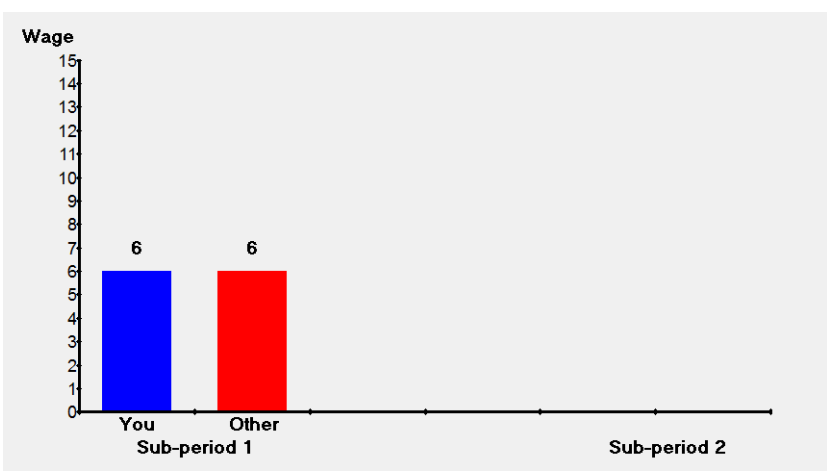

Then, in sub-period 2, your wage stays 6 EUR and the other participant's wage also stays 6 EUR:

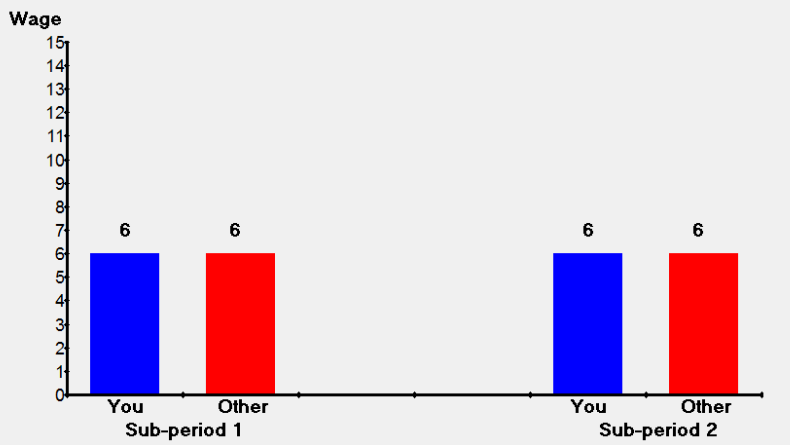




\section{Timeline}

The following timeline summarizes the different steps in this experiment.

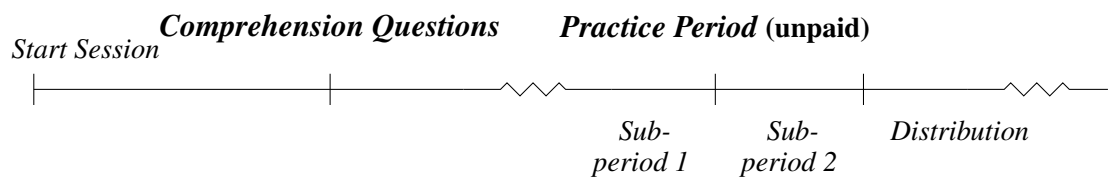

\begin{tabular}{|c|c|c|c|c|c|c|}
\hline Per & & & Per & d 2 & & Break \\
\hline $\begin{array}{c}\text { Sub- } \\
\text { period } 1\end{array}$ & $\begin{array}{c}\text { Sub- } \\
\text { period } 2\end{array}$ & Distribution & $\begin{array}{c}\text { Sub- } \\
\text { period } 1\end{array}$ & $\begin{array}{c}\text { Sub- } \\
\text { period } 2\end{array}$ & Distribution & \\
\hline
\end{tabular}

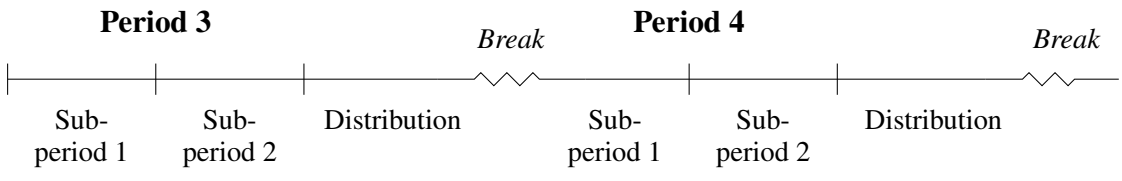

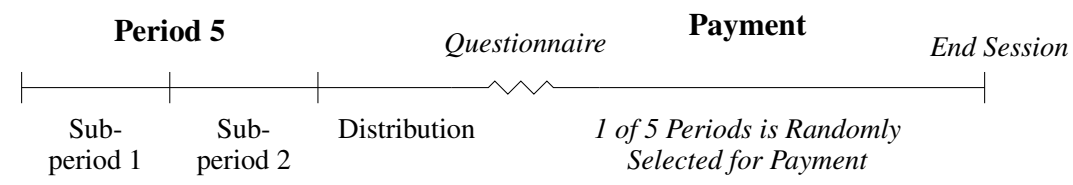

We call participants one by one at the end of the session to pay them. Please stay seated in your cubicle while you wait. 


\section{B Screenshots}

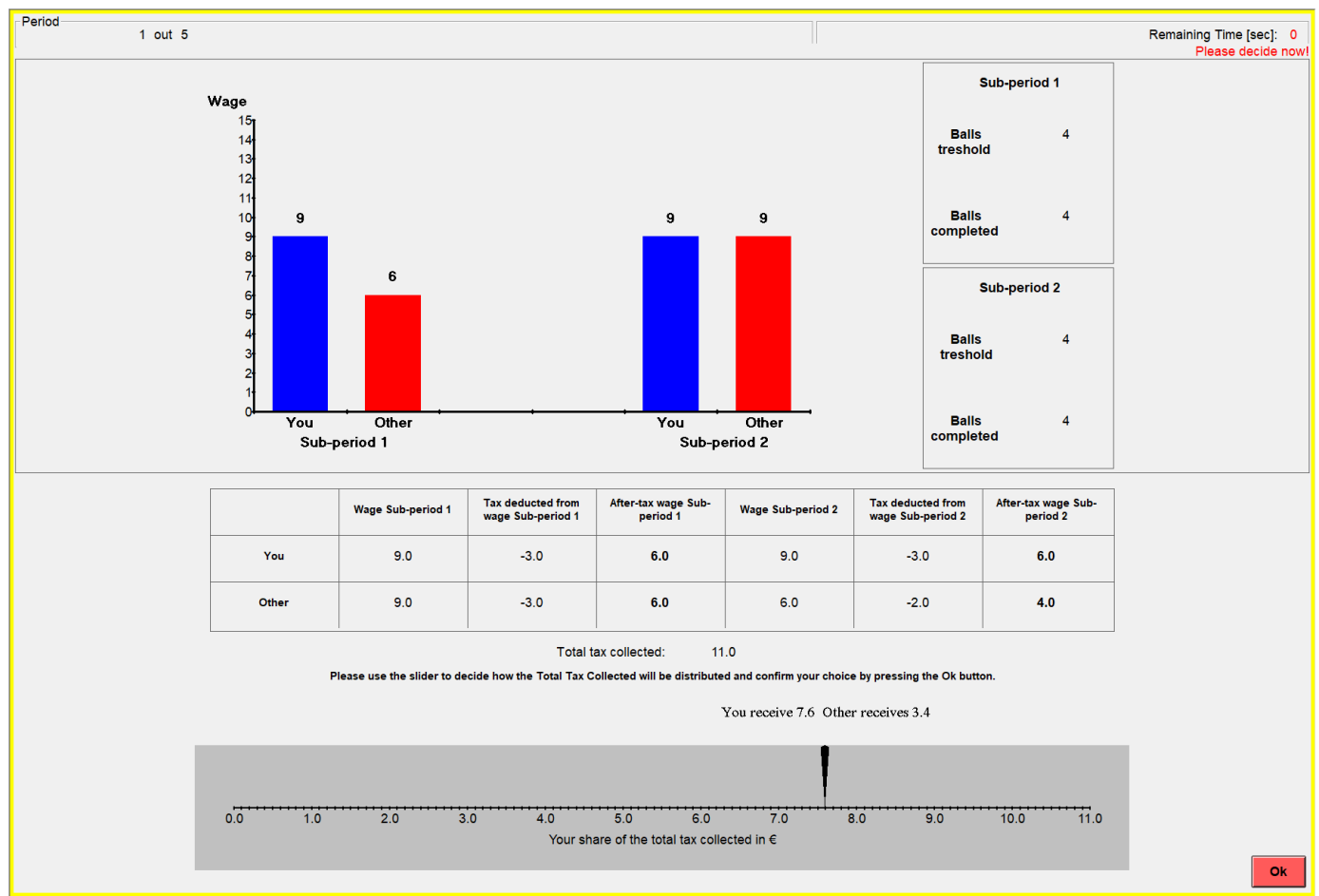

Figure B.1: Screenshot of redistribution stage (CATCHING UP treatment) 


\section{Random-Effects Tobit regressions}

Table C.1: Tests of hypotheses

\begin{tabular}{|c|c|c|}
\hline & High Earners & $\begin{array}{c}\text { One-sided } \\
p \text {-value }\end{array}$ \\
\hline \multirow[t]{2}{*}{$\mathrm{H} 1$} & $\begin{array}{r}\text { CATCHING UP, } \\
\text { INTER-PERSONAL DECREASE }< \\
\text { STABLE, } \\
\text { INTER-PERSONAL INCREASE, } \\
\text { INTRA/INTER-PERSONAL CHANGE }\end{array}$ & 0.054 \\
\hline & Low Earners & \\
\hline $\mathrm{H} 2$ & $\begin{array}{r}\text { INTRA/INTER-PERSONAL CHANGE, } \\
\text { INTRA-PERSONAL DECREASE }< \\
\text { STABLE, } \\
\text { INTRA-PERSONAL INCREASE, } \\
\text { CATCHING UP }\end{array}$ & 0.180 \\
\hline $\mathrm{H} 3$ & $\begin{array}{r}\text { INTRA/INTER-PERSONAL CHANGE }< \\
\text { StABLE, } \\
\text { INTRA-PERSONAL DECREASE, } \\
\text { INTRA-PERSONAL INCREASE, } \\
\text { CATCHING UP }\end{array}$ & 0.055 \\
\hline $\mathrm{H} 4$ & $\begin{array}{r}\text { INTRA/INTER-PERSONAL CHANGE }< \\
\text { INTRA-PERSONAL DECREASE }\end{array}$ & 0.146 \\
\hline
\end{tabular}

Note: We employ a parametric random-effects Tobit regression, which includes four period dummies to account for decreasing generosity over the course of the experiment. In line with our directed hypotheses, we present one-sided p-values. 
Table C.2: Random-effects Tobit regressions

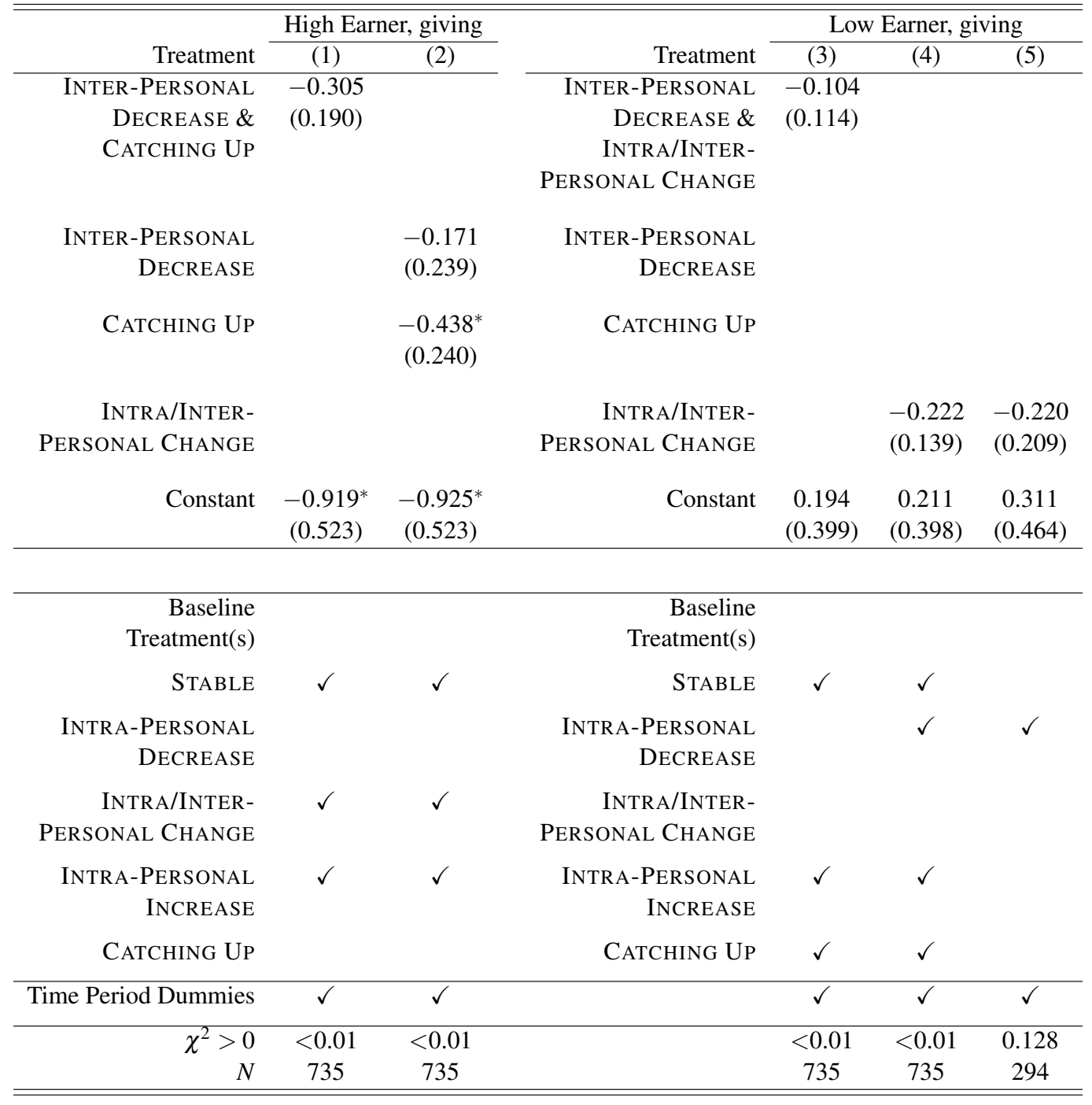

Standard errors in parentheses. Unlike when we test the directed hypotheses, we use two-sided $p$-values here for simplicity: * $\mathrm{p}<0.10,{ }^{* *} \mathrm{p}<0.05,{ }^{* * *} \mathrm{p}<0.01$ 
Table C.3: Random-effects Tobit regressions with individual treatments

\begin{tabular}{rcc}
\hline \hline & \multicolumn{2}{c}{ Giving } \\
Treatment & High Earner & Low Earner \\
\hline INTRA-PERSONAL DECREASE & -0.171 & 0.057 \\
& $(0.293)$ & $(0.175)$ \\
INTRA-PERSONAL INCREASE & 0.107 & -0.117 \\
& $(0.289)$ & $(0.176)$ \\
INTRA/INTER-PERSONAL CHANGE & -0.114 & -0.176 \\
& $(0.289)$ & $(0.175)$ \\
CATCHING UP & -0.441 & 0.243 \\
& $(0.291)$ & $(0.174)$ \\
& $-0.917^{*}$ & 0.177 \\
Constant & $(0.556)$ & $(0.412)$ \\
\hline Baseline Treatment & STABLE & STABLE \\
\hline$\chi^{2}>0$ & 0.010 & $<0.01$ \\
$N$ & 735 & 735 \\
\hline \hline
\end{tabular}

Standard errors in parentheses. Unlike when we test the directed hypotheses, we use two-sided $p$-values here for simplicity: ${ }^{*} \mathrm{p}<0.10,{ }^{* *} \mathrm{p}<0.05,{ }^{* * *} \mathrm{p}<0.01$ 


\section{Non-Selfish-individuals giving at least once}

Table D.1: Tests of hypotheses, individuals giving at least once

\begin{tabular}{|c|c|c|c|}
\hline & High Earners & $\begin{array}{l}\text { Change in } \\
\text { giving }\end{array}$ & $\begin{array}{c}\text { One-sided } \\
p \text {-value }\end{array}$ \\
\hline \multirow[t]{2}{*}{$\mathrm{H} 1$} & $\begin{array}{r}\text { CATCHING UP, } \\
\text { INTER-PERSONAL DECREASE }< \\
\text { StABLE, } \\
\text { INTER-PERSONAL INCREASE, } \\
\text { INTRA/INTER-PERSONAL CHANGE }\end{array}$ & $\begin{array}{c}-0.256 \text { Euro } \\
(-8.38 \%)\end{array}$ & 0.010 \\
\hline & \multicolumn{3}{|l|}{ Low Earners } \\
\hline $\mathrm{H} 2$ & $\begin{array}{r}\text { INTRA/INTER-PERSONAL CHANGE, } \\
\text { INTRA-PERSONAL DECREASE }< \\
\text { STABLE, } \\
\text { INTRA-PERSONAL INCREASE, } \\
\text { CATCHING UP }\end{array}$ & $\begin{array}{c}-0.090 \text { Euro } \\
(-3.61 \%)\end{array}$ & 0.132 \\
\hline H3 & $\begin{array}{r}\text { INTRA/INTER-PERSONAL CHANGE }< \\
\text { STABLE, } \\
\text { INTRA-PERSONAL DECREASE, } \\
\text { INTRA-PERSONAL INCREASE, } \\
\text { CATCHING UP }\end{array}$ & $\begin{array}{c}-0.132 \text { Euro } \\
(-5.33 \%)\end{array}$ & 0.068 \\
\hline $\mathrm{H} 4$ & $\begin{array}{r}\text { INTRA/INTER-PERSONAL CHANGE }< \\
\text { INTRA-PERSONAL DECREASE }\end{array}$ & $\begin{array}{c}-0.103 \text { Euro } \\
(-4.22 \%)\end{array}$ & 0.483 \\
\hline $\begin{array}{l}\text { Joint } \\
\text { H2-4 }\end{array}$ & 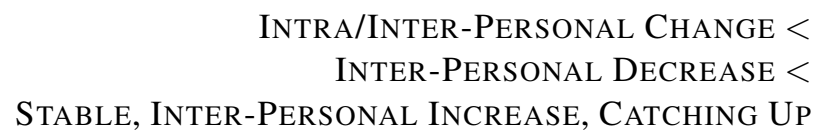 & & 0.033 \\
\hline $\begin{array}{l}\text { Not } \\
\text { pan } \\
\text { hyp } \\
\text { ther } \\
\text { whi }\end{array}$ & $\begin{array}{l}\text { Change in giving corresponds to the difference in Euro and percent } \\
\text { rom the } 11 \text {-Euro joint account between different sets of treatments. In } \\
\text { heses, for } \mathrm{H} 1-4 \text { we report one-sided } p \text {-values of non-parametric Wilcc } \\
\text { ore, we report the one-sided } p \text {-value for a joint test of } \mathrm{H} 2-4 \text {. We use } \\
\text { evaluates whether population means follow a pre-specified order. For b } \\
\text { per individual over each of the two treatment sets under consideration. }\end{array}$ & $\begin{array}{l}\text { distributed to } \\
\text { ine with the direc } \\
\text { on signed-rank t } \\
\text { age's test for or } \\
\text { h WSR and Page }\end{array}$ & $\begin{array}{l}\text { e other partici } \\
\text { ed nature of ou } \\
\text { sts (WSR). Fur } \\
\text { red alternative }\end{array}$ \\
\hline
\end{tabular}


Table D.2: Analysis for Low and High Earners pooled together, individuals giving at least once

\begin{tabular}{ccc}
\hline \hline & $\begin{array}{c}\text { Change in } \\
\text { giving }\end{array}$ & $\begin{array}{c}\text { One-sided } \\
p \text {-value }\end{array}$ \\
\hline DECREASING $<$ OTHER & $\begin{array}{c}-0.17 \text { Euro } \\
(-6.09 \%)\end{array}$ & 0.011 \\
& \\
\hline \hline
\end{tabular}

Note: Change in giving corresponds to the difference in Euro and percentage. The set DECREASING contains treatments CATCHING UP and InTRA-PERSONAL DECREASE for High Earners, and INTRA/INTER-PERSONAL CHANGE and INTRA-PERSONAL DECREASE for Low Earners. The set OTHER contains all treatments excluded from DECREASING for High and Low Earners. We report one-sided $p$-values of non-parametric Wilcoxon signed-rank test (WSR). Giving is averaged per individual over each of the two treatment sets under consideration. 


\section{E Non-Altruists-individuals giving less than 9 Euro}

Table E.1: Tests of hypotheses, individuals giving less than 9 Euro

\begin{tabular}{|c|c|c|c|}
\hline & High Earners & $\begin{array}{l}\text { Change in } \\
\text { giving }\end{array}$ & $\begin{array}{l}\text { One-sided } \\
p \text {-value }\end{array}$ \\
\hline \multirow[t]{2}{*}{$\mathrm{H} 1$} & $\begin{array}{r}\text { CATCHING UP, } \\
\text { INTER-PERSONAL DECREASE }< \\
\text { StABle, } \\
\text { INTER-PERSONAL INCREASE, } \\
\text { InTRA/INTER-PERSONAL CHANGE }\end{array}$ & $\begin{array}{c}-0.15 \text { Euro } \\
(-9.79 \%)\end{array}$ & 0.030 \\
\hline & \multicolumn{3}{|l|}{ Low Earners } \\
\hline $\mathrm{H} 2$ & $\begin{array}{r}\text { INTRA/INTER-PERSONAL CHANGE, } \\
\text { INTRA-PERSONAL DECREASE }< \\
\text { StABLE, } \\
\text { INTRA-PERSONAL INCREASE, } \\
\text { CATCHING UP }\end{array}$ & $\begin{array}{c}-0.04 \text { Euro } \\
(-2.61 \%)\end{array}$ & 0.254 \\
\hline H3 & $\begin{array}{r}\text { INTRA/INTER-PERSONAL ChANGE }< \\
\text { StABLE, } \\
\text { INTRA-PERSONAL DECREASE, } \\
\text { INTRA-PERSONAL INCREASE, } \\
\text { CATCHING UP }\end{array}$ & $\begin{array}{c}-0.04 \text { Euro } \\
(-1.90 \%)\end{array}$ & 0.134 \\
\hline $\mathrm{H} 4$ & $\begin{array}{r}\text { INTRA/INTER-PERSONAL CHANGE }< \\
\text { INTRA-PERSONAL DECREASE }\end{array}$ & $\begin{array}{c}-0.03 \text { Euro } \\
(-1.93 \%)\end{array}$ & 0.841 \\
\hline Joint & $\begin{array}{r}\text { Intra/INTER-PERSONAL CHANGE }< \\
\text { INTER-PERSONAL DECREASE }< \\
\text { StABle, INTER-PERSONAL INCREASE, CATCHING UP }\end{array}$ & & 0.038 \\
\hline & $\begin{array}{l}\text { In line with the directed nature of our hypotheses, for } \mathrm{H} 1-4 \text { and the pc } \\
\text { ues of non-parametric Wilcoxon signed-rank tests (WSR) which evalu } \\
\text { differ in the case of repeated measurements. Furthermore, we report th } \\
\text {-4 for which we use Page's test for ordered alternatives which evaluates } \\
\text { specified order. }\end{array}$ & $\begin{array}{l}\text { oled analysis we } \\
\text { tes whether two } \mathrm{P} \\
\text { e one-sided } p \text {-valu } \\
\text { whether populati }\end{array}$ & $\begin{array}{l}\text { port one-sidec } \\
\text { pulation mean } \\
\text { for a joint tes } \\
\text { means follow }\end{array}$ \\
\hline
\end{tabular}


Table E.2: Analysis for Low and High Earners pooled together, individuals giving less than 9 Euro

\begin{tabular}{ccc}
\hline \hline & $\begin{array}{c}\text { Change in } \\
\text { giving }\end{array}$ & $\begin{array}{c}\text { One-sided } \\
p \text {-value }\end{array}$ \\
\hline DECREASING $<$ OTHER & $\begin{array}{c}-0.09 \text { Euro } \\
(-6.09 \%)\end{array}$ & 0.018 \\
\hline
\end{tabular}

Note: Change in giving corresponds to the difference in Euro and percentage. The set DECREASING contains treatments CATCHING UP and INTRA-PERSONAL DECREASE for High Earners, and Intra/Inter-Personal Change and Intra-Personal DeCREASE for Low Earners. The set OTHER contains all treatments excluded from DECREASING for High and Low Earners. We report one-sided $p$-values of non-parametric Wilcoxon signed-rank test (WSR). Giving is averaged per individual over each of the two treatment sets under consideration. 